\section{KUALITAS SISTEM INFORMASI AKUNTANSI ZAKAT DI INDONESIA}

Secara khusus dalam buku ini membahas mengenai Kualitas Sistem Informasi Akuntansi Dan Kompetensi Pengguna. Kualitas Sistem Informasi Akuntansi merupakan hal yang sangat penting bagi suatu organisasi. Melalui Sistem Informasi Akuntansi yang berkualitas, user akan memperoleh informasi yang berkualitas pada saat yang tepat untuk pengambilan keputusan. Pengertian sistem informasi menurut O'Brien dan Marakas (2010:4) merupakan kombinasi yang terorganisir yang terdiri dari orang, perangkat keras, perangkat lunak, jaringan komunikasi, sumber data dan kebijakan dan prosedur yang menyimpan, mengubah dan menyebarkan informasi dalam sebuah organisasi. Stair and Reynolds (2012:32) mengatakan bahwa "a quality information system is usually flexible, efficient, accessible, and timely", pendapat tersebut menyiratkan bahwa sistem informasi yang berkualitas biasanya fleksibel, efesien, mudah diakses, dan tepat waktu. Sedangkan menurut Weber (1999:895), kualitas sistem adalah serangkaian karekteristik yang akan terlihat oleh pengguna ketika mereka berinteraksi dengan menggunakan sistem pada suatu periode tertentu ("one set of characteristics will be fairly apparent to users after they have interact with the system for only a short periode tima").

Kenyataan dilapangan khususnya di Badan Amil Zakat Nasional (BAZNAS), sebagaimana yang diungkapkan oleh Fuad Nashar (2013) sekretaris BAZNAS Pusat bahwa belum tertatanya sistem pelaporan zakat yang terintegrasi secara nasional mengakibatkan laporan keuangan BAZNAS kabupaten dan kota seluruh Indonesia tidak tepat waktu. Demikan pula yang dikemukakan Ketua BAZNAS Pusat (Didin Hafidhuddin, 2014), bahwa belum terintegrasinya database pemberi zakat (muzaki) dan penerima zakat (mustahik) mengakibatkan belum optimalnya penghimpunan dan penyaluran dana zakat di Indonesia. Senada dengan pendapat tersebut, Bambang Sudibyo (2014), menyatakan bahwa lemahnya sistem informasi akuntansi keuangan di BAZNAS salah satunya disebabkan tidak terintegrasinya data akuntansi, yang menyebabkan penerimaan dana zakat masih jauh dari potensi yang ada (Didin Hafidhuddin, 2013). Fenomena yang terjadi pada organisasi di Indonesia menunjukkan bahwa sistem informasi akuntansi belum berkualitas sehingga berdampak pada belum berkualitasnya informasi akuntansi.
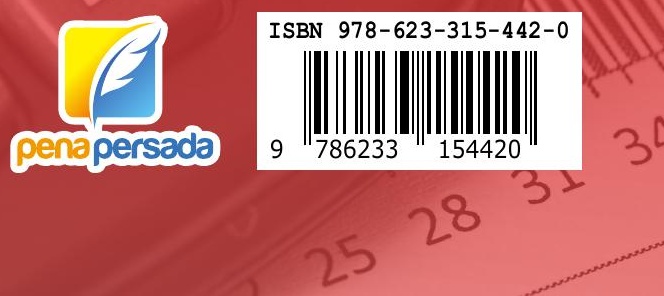

\section{KUALITAS SISTEM INFORMASI} AKUNTANSI

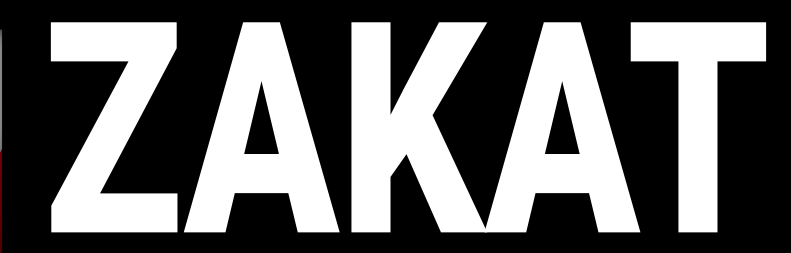

DI INDONESIA

二



\section{NUNUNG NURHAYATI}




\section{KUALITAS SISTEM INFORMASI AKUNTANSI ZAKAT DI INDONESIA}

NUNUNG NURHAYATI

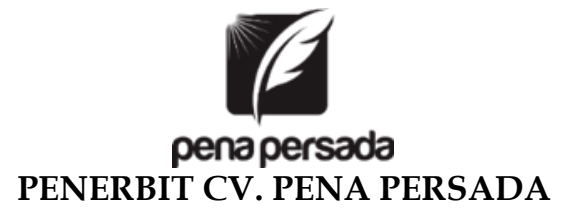




\title{
KUALITAS SISTEM INFORMASI AKUNTANSI ZAKAT DI INDONESIA
}

\author{
Penulis: \\ Nunung Nurhayati
}

ISBN: 978-623-315-442-0

\author{
Editor: \\ Wiwit Kurniawan \\ Design Cover: \\ Retnani Nur Briliant \\ Layout: \\ Nisa Falahia

\section{Penerbit CV. Pena Persada} \\ Redaksi:
}

Jl. Gerilya No. 292 Purwokerto Selatan, Kab. Banyumas Jawa

Tengah

Email: penerbit.penapersada@gmail.com Website:

penapersada.com Phone: (0281) 7771388

Anggota IKAPI

All right reserved Cetakan pertama: 2021

Hak Cipta dilindungi oleh undang-undang. Dilarang memperbanyak karya tulis ini dalam bentuk apapun tanpa izin penerbit 


\section{KATA PENGANTAR}

Segala puji senantiasa kita panjatkan kehadirat Allah Swt, atas segala rahmat dan karunianya, akhirnya penulis dapat menyelesaikan penyusunan buku yang berjudul "KUALITAS SISTEM INFORMASI AKUNTANSI ZAKAT DI INDONESIA". Saya menyadari bahwa tanpa bantuan dan bimbingan dari berbagai pihak sangatlah sulit bagi saya untuk menyelesaikan karya ini. Oleh karena itu, saya mengucapkan banyak terima kasih pada semua pihak yang telah membantu penyusunan buku ini. Sehingga buku ini bisa hadir di hadapan pembaca.

Kualitas Sistem Informasi Akuntansi merupakan hal yang sangat penting bagi suatu organisasi. Melalui Sistem Informasi Akuntansi yang berkualitas, user akan memperoleh informasi yang berkualitas pada saat yang tepat untuk pengambilan keputusan. Fenomena yang terjadi pada organisasi di Indonesia menunjukkan bahwa sistem informasi akuntansi belum berkualitas sehingga berdampak pada belum berkualitasnya informasi akuntansi.

Penulis menyadari bahwa buku ini masih jauh dari kesempurnaan. Oleh karena itu kritik dan saran yang membangun sangat dibutuhkan guna penyempurnaan buku ini. Akhir kata saya berharap Allah Swt berkenan membalas segala kebaikan semua pihak yang telah membantu

Penulis 


\section{DAFTAR ISI}







BAB II. KUALITAS SISTEM INFORMASI AKUNTANSI................. 4

A. Konsep Sistem Informasi................................................. 4

B. Sistem Informasi Akuntansi............................................ 6

C. Kualitas Sistem Informasi Akuntansi ..............................

BAB III KUALITAS INFORMASI AKUNTANSI .............................13

BAB IV PROBLEMATIKA SISTEM INFORMASI AKUNTANSI ZAKAT

BAB V. KUALITAS SISTEM INFORMASI AKUNTANSI

ZAKAT DI BAZNAS

A. Gambaran Sistem Yang digunakan Di Baznas

Kab/Kota di Pulau Jawa ..............................................23

B. Gambaran Kualitas Sistem Informasi di Baznas ........26

BAB VI KUALITAS INFORMASI AKUNTANSI ZAKAT DI

BAZNAS

BAB VII. MODEL KUALITAS SISTEM INFORMASI

TERHADAP KUALITAS INFORMASI AKUNTANSI ZAKAT

A. Model Pengukuran (Outer Model) ................................... 45



C. Pengaruh Kualitas Sistem Informasi Akuntansi Terhadap Kualitas Informasi Akuntansi......................55

D. Hasil pengujian hipotesis .................................................

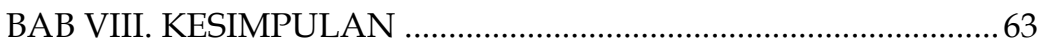

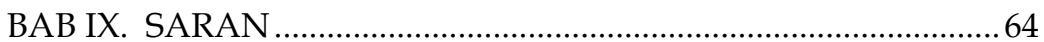

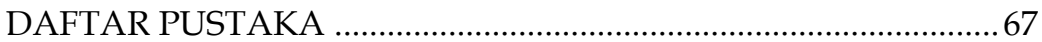




\section{BAB I. PENDAHULUAN}

Informasi merupakan data yang telah diolah menjadi bentuk yang bermanfaat dan berguna bagi para pengguna (Laudon \& Laudon, 2016:48). Hal yang sama diungkapkan oleh Azhar Susanto (2013:38) bahwa informasi adalah hasil dari pengolahan data yang memberikan arti dan manfaat. Lebih lanjut Azhar Susanto (2013:51) menjelaskan bahwa nilai suatu informasi tergantung kepada kualitas informasi yang disajikan. Informasi yang berkualitas merupakan salah satu keunggulan kompetitif bagi suatu organisasi (Xu, 2009:1). Semakin baik kualitas informasi yang dimiliki oleh suatu organisasi, maka akan semakin baik pula komunikasi yang terjadi didalamnya (Azhar Susanto, 2013:11).

McLeod \& Schell (2007:35), mengatakan bahwa informasi yang berkualitas apabila memenuhi kriteria akurat, tepat waktu, relevan dan lengkap. Sementara Romney \& Steinbart (2015:30) menyatakan bahwa informasi yang berkualitas dapat dilihat dari kriteria relevant, reliable, complete, timely, understandable, verifable dan accessible. Informasi dikatakan relevan apabila informasi yang diberikan kepada pengguna sesuai dengan yang dibutuhkan oleh individu di berbagai tingkatan dan bagian dalam organisasi (Azhar Susanto, 2013:38). Selanjutnya informasi dikatakan akurat apabila informasi terbebas dari pengertian yang menyesatkan dan kesalahan material, serta informasi tersebut menyajikan setiap fakta secara jujur dan dapat diverifikasi (McLeod \& Schell, 2007:35), berikutnya informasi dikatakan tepat waktu apabila informasi yang disajikan tersedia setiap saat ketika dibutuhkan bagi pengambilan keputusan (Romney \& Steinbart, 2015:30). Sedangkan informasi dikatakan lengkap jika informasi yang dihasilkan telah selengkap apa yang diinginkan dan 
dibutuhkan pengguna (Azhar Susanto, 2013:13).

Fenomena di lapangan menunjukkan bahwa kualitas informasi akuntansi yang digunakan dalam suatu lembaga/perusahaan masih rendah (Fuad Rahmany, 2014; Ali Maskur Musa, 2014; Agus Martowardojo, 2013; Fuad Nashar, 2013; Hadi Poernomo,2014; Reydonnyzar Moenek, 2015). Pada perusahaan sektor publik, sebagaimana yang diungkapkan oleh Ketua Komite Perpajakan, Fuad Rahmany (2014), bahwa tidak optimalnya penerimaan pajak karena belum akuratnya data NPWP. Hal serupa juga dikatakan oleh anggota IV Badan Pemeriksa Keuangan, Ali Masykur Musa (2014), bahwa data yang berkaitan dengan produksi mineral dan batubara sangat lemah atau tidak akurat. Informasi yang tidak akurat mengakibatkan manajemen salah dalam mengambil keputusan (Ali Masykur Musa, 2014).Demikian pula yang diungkapkan oleh Agus Martowardojo (2013) bahwa terdapat 10 Kementrian/Lembaga yang memiliki laporan keuangan yang tidak berkualitas.

Permasalahan lain yang berhubungan dengan rendahnya kualitas informasi akuntansi dikemukakan oleh Hadi Poernomo (2011) yang menyatakan bahwa 326 Pemda atau 91\% dari 358 Pemda yang laporan keuangannya diaudit oleh BPK dinyatakan tidak berkualitas, hanya 32 Pemda yang mendapatkan opini wajar tanpa pengecualian. Demikian juga yang diungkapkan oleh Dirjen Keuangan daerah Kemendagri, Reydonnyzar Moenek (2015) yang menyatakan anggaran yang diajukan KPUD kepada pemerintah Daerah (Pemda) dinilai tidak relevan dan tidak rasional sehingga Pemda melakukan rasionalisasi dan prinsip kehati-hatian.

Demikian juga yang terjadi di lembaga Pengelolaan Zakat, sebagaimana yang dikemukanan Fuad Nasar (2013) Wakil Sekretaris Badan Amil Zakat Nasional (BAZNAS) Pusat menyatakan bahwa laporan keuangan/informasi akuntansi yang disampaikan oleh Baznas Kabupaten/Kota yang ada di seluruh Indonesia, masih banyak yang belum tepat waktu, 
yang berdampak penerimaan dana zakat masih rendah.

Melihat peran informasi yang begitu tinggi bagi organisasi maka organisasi menjadi tergantung pada sistem informasi akuntansi (Azhar Susanto, 2013:11). Hal yang sama diungkapkan oleh Wongsim \& Jing Gao (2011:1) bahwa informasi yang berkualitas dihasilkan oleh sistem informasi yang berkualitas. Hal ini senada dengan pernyataan O'Brien \& Marakas (2010:353) bahwa user membutuhkan informasi yang berkualitas karena informasi yang berkualitas akan meningkatkan nilai keputusan yang akan diambil oleh perusahaan.

Kualitas Sistem informasi dapat dinyatakan berkualitas jika memiliki karakteristik diantaranya (1) integrasi yaitu perpaduan/ penggabungan bagian-bagian atau komponenkomponen dari sistem dalam mencapai fungsi yang lebih baik sesuai dengan harapan (Norman, 2014:15; Heidmann, 2008:87) dan harmonis (Azhar Susanto, 2013: 73-83), (2) accessibility yaitu sistem mudah diakses (Stair \& Reynold, 2016:8; Laudon \&Laudon, 2016:505; Wixon \& Tod, 2005; Heidmann, 2008:89), (3) flexibility yaitu kemampuan sistem untuk melakukan penyesuaian atau beradaptasi terhadap perubahan kebutuhan sistem (Heidmann, 2008:88; Peter, 2008; Weygandt et.al, 2012:316; DeLone \& McLean, 2003:13) dan (4) .ease of use yaitu sistem mudah digunakan (Romney \& Steinbart, 2012:615; Wixom \& Tod, 2005:88; DeLone \& McLean, 2003:13), 


\section{BAB II. \\ KUALITAS SISTEM INFORMASI \\ AKUNTANSI}

\section{A. Konsep Sistem Informasi}

Sebelum menjelaskan tentang kualitas sistem informasi akuntansi, terlebih dahulu penulis perlu membahas tentang konsep sistem informasi. Menurut Gelinas et al.,(2008:13)" An Information system is a man made system that generally consists of an integrated set of computer based components and manual components established to collect, store and manage data and provide output information to users", maksudnya sistem informasi adalah suatu sistem buatan manusia yang umumnya terdiri dari serangkaian komponen terpadu berbasis komputer dan komponen pengguna didirikan untuk mengumpulkan, menyimpan dan mengelola data dan menghasilkan output informasi kepada pengguna Gelinas, et al., ( 2008:13)

Pernyataan di atas sejalan dengan pernyataan Laudon \& Laudon (2016:48) yang mengemukakan bahwa sebuah sistem informasi dapat didefinisikan sebagai serangkaian komponen yang saling berhubungan untuk mengumpulkan, memproses, menyimpan dan mendistribusikan informasi dalam rangka mendukung pengambilan keputusan dalam suatu organisasi ("An information system can be defined technically as a set of interrelated components that collect (for retrieve), process, store, and distribute information to support decision making and control in an organization")

Sementara O'Brien dan Marakas (2010:4) menyebutkan pengertian sistem informasi lebih detail sebagai berikut:

Information System can be any organized combination of people, hardware, software, communications networks, data 
resources and policies and procedures that stores, retrives, transforms and disseminates information in an organization. People rely on modern information systems to communicate with one another using a variety of physical devices (hardware), information processing instructions and procedures (software), communications channels (networks), and stored data (data resources)

Pengertian sistem informasi menurut O'Brien dan Marakas (2010:4) merupakan kombinasi yang terorganisir yang terdiri dari orang, perangkat keras, perangkat lunak, jaringan komunikasi, sumber data dan kebijakan dan prosedur yang menyimpan, mengubah dan menyebarkan informasi dalam sebuah organisasi. Orang mengandalkan pada sistem informasi untuk berkomunikasi satu sama lain dengan menggunakan berbagai perangkat keras, instruksi pemrosesan informasi dan procedure, perangkat lunak, saluran komunikasi dan sumber data. Pernyataan di atas sejalan dengan pernyataan Azhar Susanto (2013: 52) yang memberikan pengertian sistem informasi sebagai" kumpulan dari sub-sub sistem baik phisik maupun non phisik yang saling berhubungan satu sama lain dan bekerja sama secara harmonis untuk mencapai satu tujuan yaitu mengolah data menjadi informasi yang berguna. Sementara itu menurut James Hall (2011:7) mengungkapkan definisi sistem informasi adalah serangkaian prosedur formal yang mengumpulkan, memproses data menjadi informasi dan mendistribusikannya kepada pengguna ("the information system is the set of formal procedures by which data are collected, processed into information, and distributed to users").

Berdasarkan pengertian-pengertian di atas maka dapat dikatakan bahwa sistem informasi adalah kumpulan dari komponen-komponen organisasi yang saling berhubungan untuk mencapai suatu tujuan yaitu menyajikan informasi yang berguna bagi pengambilan keputusan (pengguna). 


\section{B. Sistem Informasi Akuntansi}

Sistem informasi akuntansi adalah mengumpulkan, mencatat dan memproses data untuk menghasilkan informasi yang dibutuhkan para pemakainya (Romney \&Steinbart (2012:30), Selanjutnya Bodnar dan Hopwood (2010:1) mendefinisikan sistem informasi akuntansi sebagai berikut:" An accounting information system is a collection of resoures, such as people and equipment, designed to transform financial data into information. This information is communicated to a wide variety of decision makers".

Sedangkan Azhar Susanto (2013: 72) menyatakan bahwa: Sistem informasi akuntansi dapat didefinisikan sebagai kumpulan (integrasi) dari sub-sub sistem /komponen baik fisik maupun non fisik yang saling berhubungan dan bekerja sama satu sama lain secara harmonis untuk mengolah data transaksi yang berkaitan dengan masalah keuangan menjadi informasi keuangan

James Hall (2011:7) menyatakan bahwa: "The Accounting Information System/ AIS subsystems process financial transactions and nonfinancial transaction that directly affect the processing of financial transactions". Hal senada diungkapkan oleh Sri Mulyani NS (2009:14), bahwa sistem informasi akuntansi sekarang disebut dengan istilah transaction processing system, yang artinya sebuah sistem komputer didesain untuk mengolah transaksi yang tidak hanya terbatas pada database atau file system, namun juga melakukan pengolahan beberapa operasi transaksi dimana semua transaksi harus berhasil atau semua transaksi harus dibatalkan Sedangkan Wilkinson et al.,(2000:7) menyatakan bahwa: "An accounting information system is a unified structure within an entity, such as a business firm, that employs physical resources and other components to transform economic data into acoounting information, with the purpose of satisfying the information needs of a variety of users". 
Pendapat di atas dapat diartikan bahwa sistem informasi akuntansi adalah struktur yang terpadu dalam suatu entitas yang mengolah sumber daya fisik dan komponen lainnya untuk mengubah data ekonomi menjadi informasi akuntansi, dengan tujuan untuk memenuhi kebutuhan informasi bagi penggunanya (Wilkinson et al.,2000;7). Sedangkan Bagranoff et al.,(2010:8) pengatakan pengertian sistem informasi akuntansi adalah sebagai berikut:" An accounting information system is a collection of data and processing procedures that creates needed information for its users. AIS as a set of components that collet accounting data, store it for future uses, and process it for end users".

Pendapat di atas dapat dikatakan bahwa sistem informasi akuntansi adalah kumpulan data dan prosedur pengolahan yang menghasilkan informasi yang diperlukan bagi penggunanya. Sistem informasi akuntansi sebagai seperangkat komponen yang mengumpulkan data akuntansi, menyimpannya untuk penggunaan masa depan dan proses untuk pengguna akhir (Bagranoff, et al., 2010:8).

Berdasarkan teori-teori yang dikemukakan tersebut di atas, maka dapat dikatakan bahwa sistem informasi akuntansi adalah kumpulan komponen-komponen dalam organisasi yang saling bekerja sama satu sama lain untuk mengolah data keuangan menjadi informasi keuangan.

\section{Kualitas Sistem Informasi Akuntansi}

Stair and Reynolds (2012:32) mengatakan bahwa "a quality information system is usually flexible, efficient, accessible, and timely", pendapat tersebut menyiratkan bahwa sistem informasi yang berkualitas biasanya fleksibel, efisien, mudah diakses, dan tepat waktu. Sedangkan menurut Weber (1999:895), kualitas sistem adalah serangkaian karakteristik yang akan terlihat oleh pengguna ketika mereka berinteraksi dengan menggunakan sistem pada suatu periode tertentu ("one set of characteristics will be fairly 
apparent to users after they have interact with the system for only a short periode tima").

DeLone \& Mclean (2003) menggunakan istilah kesuksesan untuk menunjukkan kualitas sistem informasi, yang berfokus untuk menghasilkan informasi yang berkualitas. Selanjutnya Azhar Susanto, (2013:374) menyatakan bahwa peran mendasar sistem informasi akuntansi dalam organisasi sebagai penampung dan pengolah data akuntansi untuk menghasilkan informasi akuntansi yang berkualitas. Sedangkan Gelinas, et al., (2012:34) menggunakan istilah efektivitas sistem informasi akuntansi sebagai ukuran kesuksesan sistem informasi dalam mencapai tujuan yang telah ditetapkan.

Bagranoff, et al., (2010:5) menyatakan bahwa kualitas sistem informasi akuntansi adalah kumpulan data dan prosedur pengolahan data yang menghasilkan informasi akuntansi yang dibutuhkan bagi pengguna. Hal ini senada dengan yang diungkapkan oleh Sri Mulyani NS (2009: 25), bahwa sistem informasi akuntansi yang berkualitas dapat membantu mengambil keputusan dengan tepat.

Berdasarkan uraian di atas yang dimaksud dengan kualitas sistem informasi akuntansi adalah kemampuan sistem informasi akuntansi dalam menyediakan informasi akuntansi yang berkualitas yang berguna bagi pengambilan keputusan (Azhar Susanto,2013:72 ; Sri Mulyani NS, 2009: 25; Bagranoff, et al., 2010:5) .

Adapun dimensi dan indikator dari kualitas sistem informasi akuntansi, sebagaimana yang diungkapkan oleh Stair \& Reynold (2012:32) bahwa kualitas sistem informasi dapat diukur dengan dimensi: flexible, efficient, accessible, and timely. Selanjutnya Delone \& Mclean (2003) menunjukkan bahwa kualitas sistem informasi dapat diukur dengan dimensi: ease of use, system flexibility, sistem realibility dan ease of learning. Sedangkan Kieso, et al., (2012:316) menyatakan bahwa quality of accounting information system is based on: 1) 
Cost effectiveness, 2) Usefulness, 3) Flexibility.

Heidmann (2008:86-90) lebih detail menjelaskan dimensi dari kualitas sistem informasi akuntansi yaitu: 1) integrasi; 2) fleksibilitas; 3) aksesibilitas; 4) formalisasi dan 5) kekayaan media, dengan detailnya sebagai berikut:

1. Integration, menurut Heidmann (2008:86-90) "measures the degree to which a system facilitates the combination of information from various sources to support business decisions". Selanjutnya Whitten \& Bentley (2007:26) menambahkan bahwa integrasi dalam sistem informasi merupakan proses membangun sistem informasi yang terpadu dari berbagai komponen seperti software yang dibeli, software yang dibuat khusus, hardware, dan jaringan. Senada yang diungkapkan oleh Azhar Susanto (2013:73-83), bahwa semua komponen baik, hardware, software, brainware, procedure, database dan jaringan komunikasi dan sub komponen dari masing-masing komponen bersinergi dalam sistem informasi akuntansi untuk mengolah data keuangan yang diperlukan manajemen dalam pengambilan keputusan.

2. Flexibility, Heidmann (2008:88) menjelaskan "flexibility measures the degree to which a system can adapt to a variety of user needs and to changing condition", maksudnya bahwa sistem yang fleksibel dapat diukur pada tingkat dimana sistem tersebut dapat beradaptasi dengan berbagai macam kebutuhan pengguna dan dapat beradaptasi dengan berbagai berbagai macam perubahan kondisi yang terjadi dalam organisasi.

3. Accessibility, Heidmann (2008:89) menjelaskan bahwa "accessibility measures the degree to which a system and the information it contains can be accessed with relatively low effort". Maksudnya bahwa aksesibilitas dapat mengukur dimana sistem dan informasi yang ada di dalamnya dapat diakses dengan mudah. 
4. Formalization, Heidmann (2008:90) menjelaskan "formalization measures the degree to which a system contains rules or procedures"

5. Media Richness, Heidmann (2008:90) menjelaskan "media richness measures the degree to which a system uses channels that enable a high level of personal interaction".

Selanjutnya Weber (1999: 895) menyatakan bahwa kualitas sistem dapat diukur dengan:

1. Respon time (waktu respon) merupakan waktu tanggap yang digunakan dalam mengakses suatu sistem

2. Reability of the system merupakan sistem yang dapat diandalkan pada saat menyelesaikan pekerjaannya.

3. Ease of intraction with the system (mudah berinteraksi dengan sistem) merupakan kemampuan sistem dalam beradaptasi mengikuti perubahan yang ada di lingkungannya.

4. Usefulness of the functionally provided by the system ( kegunaan dari fungsi disediakan oleh sistem) merupakan memiliki fitur dan fungsi serta instruksi pemakaian mudah dinavigasi

5. Ease of learning (mudah dipelajari) merupakan sistem informasi mudah untuk dipelajari pengoperasiannya.

6. Quality of documentation and help facilities, dapat melakukan dokumentasi yang baik dan memiliki fasilitas bantuan

7. Extent of integration with other system (tingkat integrasi dengan sistem lain), merupakan dapat digunakan dengan flexible dalam berinteraksi dengan sistem

Romney \& Steinbart (2012: 615) menyatakan bahwa kualitas sistem informasi akuntansi (AIS's Success) meliputi:

1. Usefulness: Information output should help management and users make decisions

2. Economy: The benefits of the system should exceed the cost 
3. Realibility: The system should process data accurately and completely

4. Availability: users should be able to access the system at their convenience

5. Timeliness: crucial information should be produced first, and less important items as time permits

6. Customer Service: Courteus and efficient customer service should be provided

7. Capacity: System capacity should handle periods of peak operation and future growth

8. Ease of use: The system should be user friendly

9. Flexibility: The system should accommodate reasonable operating or system requirements changes

10. Tractability: The system should be easily understood by users and designers and facilitate problem solving and future systems development

11. Auditability: Auditability should be built into the system from the beginning

12. Security: only authorized users should be granted access or allowed to change system data.

Berdasarkan beberapa pendapat tersebut di atas, maka dimensi dan indikator yang digunakan dalam kualitas sistem informasi akuntansi adalah:

1. Integration (integrasi) yaitu perpaduan seluruh komponen sistem dan subsistem/fungsi secara harmonis (Thomas Norman, 2014:15, Heidmann, 2008:81; Azhar Susanto, 2013:73-83; Whitten, 2007:26), dengan indikator:

a. Integrasi antara komponen sistem (Azhar Susanto, 2013:73-83; Heidmann, 2008:87; Thomas Norman, 2014:15; Whitten, 2007:26; O,Brien \& Marakas, 2011:30)

b. Terintegrasi dengan subsistem lainnya (Azhar Susanto,2 013:73-83; Heidmann, 2008:87; Norman, 2014:15; Whitten, 2007:26; O,Brien \& Marakas, 2011:30) 
2. Accessibility (Mudah diakses) yaitu sistem dapat diakses dengan upaya yang relatif mudah (Heidmann, 2008:89; Romney \& Steinbart, 2012:615; Balzan, 2014:183) dengan indikator:

a. Sistem dapat diakses dengan mudah (Heidmann, 2008:89)

b. Sistem dapat diakses dimana saja (Heidmann, 2008:89; Romney \& Steinbart, 2012:615)

3. Fleksibility (Fleksibel) yaitu sistem informasi dapat diukur pada tingkat dimana sistem tersebut dapat beradaptasi dengan berbagai macam kebutuhan pengguna dan dapat beradaptasi dengan berbagai macam perubahan kondisi yang terjadi di perusahaan (Heidmann, 2008:89; Romney \& Steinbart, 2012:615; Kieso, et al., 2012:316 ; DeLone \& Mclean, 2003), dengan indikator:

a. Sistem mampu menyesuaikan kebutuhan pengguna (Heidmann, 2008:89; Romney \& Steinbart, 2012:615; Kieso, et al., 2012:316; Delone \& Mclean, 2003)

b. Sistem mampu beradaptasi dengan perubahan lingkungan (Heidmann, 2008:89) 


\section{BAB III \\ KUALITAS INFORMASI AKUNTANSI}

\section{Konsep Kualitas Informasi Akuntansi}

Informasi adalah data yang telah dibentuk menjadi sesuatu yang memiliki arti dan berguna bagi pengguna. Hal senada diungkapkan oleh Azhar Susanto (2013: 38), bahwa informasi adalah hasil pengolahan data yang memberikan arti dan manfaat. Demikian pula yang dikemukakan oleh Gelinas, et al., (2012:18) bahwa informasi merupakan data yang disajikan dalam bentuk yang berguna untuk pengambilan keputusan. Sedangkan Stair dan Reynolds (2016:17) menyatakan : “The value of information is directly linked to how it helps decision makers achieve their organization's goals. Valuable information can help people and their organizations perform tasks more efficiently and effectively.

Melihat peran informasi yang begitu penting dalam organisasi, maka user membutuhkan informasi yang berkualitas karena informasi yang berkualitas akan meningkatkan nilai keputusan yang akan diambil oleh perusahaan (O'Brien \& Marakas, 2010:353), lebih lanjut O'Brien \& Marakas (2011:644), menyatakan bahwa kualitas informasi merupakan "the degree to which information has content, form, and time characteristics that give it value to specific end users", yang maksudnya bahwa informasi yang berkualitas jika memiliki karekteristik: isi, bentuk, dan waktu yang dapat memberikan nilai kepada pengguna akhir.

Selanjutnya Turban \& Volonino (2011:431) menyatakan bahwa kualitas informasi adalah sebuah ukuran subjektif dari kegunaan, objektivitas dan integritas informasi yang didapatkan oleh pengguna ("information quaity is a subjective measures of the utility, objectivity and integrity of gathered information"). Sementara Balzan (2012:214) menyatakan bahwa 
informasi yang berkualitas adalah sebagai berikut: Information integrity is a measure of the quality of information, integrity constraints are rules that help ensure the quality of information. The database ensure that users can never violate these constraints. To ensure information system do not suffer from data integrity issues, review for the characteristics common to high quality information: accuracy, completeness, timeliness, consistency and uniquess.

Informasi yang berkualitas menurut Balzan (2014:224) adalah informasi yang terintegrasi, lebih lanjut Balzan (2014: 216-217), menyatakan bahwa informasi yang berkualitas adalah informasi harus akurat, lengkap, konsisten, tepat waktu dan unik. Sedangkan James Hall (2011:13-14) menyatakan informasi yang berkualitas dengan "useful information has the following characteristic; relevance, timeliness, accuracy, completeness, and summarization". Selanjutnya Laudon \& Laudon (2016:250) menyatakan, informasi yang berkualitas mempunyai dimensi, akurat adalah informasi yang bebas dari kesalahan, tepat waktu adalah informasi yang tepat waktu dan tersedia untuk pembuat keputusan ketika diperlukan, relevan adalah informasi yang berguna dan tepat dalam pengambilan keputusan. Sedangkan Stair \& Reynolds (2012:7) melibatkan dimensi kualitas informasi yang lebih komprehensif yaitu accessible, accurate, complete, economical, flexible, relevant, rliable, secure, simple, timely dan verifiables.

Berdasarkan uraian di atas yang dimaksud dengan informasi akuntansi yang berkualitas adalah informasi yang diterima sesuai dengan yang dibutuhkan, tersedia saat dibutuhkan dan lengkap, sehingga dapat digunakan dalam pengambilan keputusan dan memenuhi kebutuhan pengguna. Kualitas informasi akuntansi dapat diukur dengan beberapa dimensi. Menurut Gelinas, et al., (2008:20), dimensi untuk mengukur informasi yang berkualitas adalah Effectiveness, Effeciency, confidentiality, integrity, availability, compliance $\mathcal{E}$ reliability of information Pengertian setiap dimensi adalah 
sebagai berikut:

1. Effectiveness :berkaitan dengan informasi yang relevan, proses bisnis dapat disampaikan secara benar, konsisten, lengkap dan tepat waktu (deals with information being relevant and pertinent to the business process as well as being delivered in a a timely, correct, consistent, and usable manner)

2. Effeciency: berhubungan dengan penyediaan informasi melalui penggunaan optimal dari smber daya (concerns the provision of information through the optimal (most productive and economical use of resources)

3. Confidentiality; menyangkut perlindungan terhadap informasi yang menimbulkan resiko dari pengungkapan yang tidak sah (concerns the protection of sensitive information from un authorized disclosure)

4. Integrity: berkaitan dengan keakuratan dan kelengkapan informasi serta validitas sesuai dengan nilai-nilai bisnis yang diharapkan (relates to accuracy and completeness of information as well as to its validity in accordance with business values and expectations)

5. Availability: berkaitan dengan informasi yang tersedia ketika diperlukan oleh proses bisnis, termasuk pengamanan sumber daya (related to information being available when required by the business process now and in the future. Its also concerns the safe guarding of necessary resources and associated capbilities)

6. Compliance: berkaitan dengan hukum-hukum, perturan dan kewajiban kontrak proses bisnis, pada pihak eksternal (deals with complying with those laws regulations, and contractul arragements to which to business process is subject, that is, exterally imposed business criteria, as well as internal policies)

7. Reliability of information: berkaitan dengan menyediakan informasi yang sesuai bagi manajemen untuk mengoperasikan entitas, dan mengujinya untuk tanggung jawab tata kelola (related to the provision of appropriate 